\title{
Caffeine and Adenosine
}

\author{
Joaquim A. Ribeiro* and Ana M. Sebastião \\ Institute of Pharmacology and Neurosciences, Faculty of Medicine and Unit of Neurosciences, Institute of \\ Molecular Medicine, University of Lisbon, Lisbon, Portugal
}

\begin{abstract}
Caffeine causes most of its biological effects via antagonizing all types of adenosine receptors (ARs): A1, A2A, A3, and $\mathrm{A} 2 \mathrm{~B}$ and, as does adenosine, exerts effects on neurons and glial cells of all brain areas. In consequence, caffeine, when acting as an AR antagonist, is doing the opposite of activation of adenosine receptors due to removal of endogenous adenosinergic tonus. Besides AR antagonism, xanthines, including caffeine, have other biological actions: they inhibit phosphodiesterases (PDEs) (e.g., PDE1, PDE4, PDE5), promote calcium release from intracellular stores, and interfere with GABA-A receptors. Caffeine, through antagonism of ARs, affects brain functions such as sleep, cognition, learning, and memory, and modifies brain dysfunctions and diseases: Alzheimer's disease, Parkinson's disease, Huntington's disease, Epilepsy, Pain/Migraine, Depression, Schizophrenia. In conclusion, targeting approaches that involve ARs will enhance the possibilities to correct brain dysfunctions, via the universally consumed substance that is caffeine.
\end{abstract}

Keywords: Adenosine, Alzheimer's disease, anxiety, caffeine, cognition, Huntington's disease, migraine, Parkinson's disease, schizophrenia, sleep

\section{INTRODUCTION}

Caffeine causes most of its biological effects via antagonizing all types of adenosine receptors (ARs). When acting as an AR antagonist, caffeine, used acutely, is doing the opposite of activation of adenosine receptors, due to removal of the adenosinergic tonus. The adenosine $\mathrm{A} 1$ and $\mathrm{A} 2 \mathrm{~A}$ receptors have high affinity for adenosine and are those responsible for tonic actions of endogenous adenosine. So, in the present review we will focus on $\mathrm{A} 1$ and $\mathrm{A} 2 \mathrm{~A}$ adenosine receptors and on the mechanisms they operate in order to infer how caffeine exerts most of its actions in the brain. There are many studies reporting actions of caffeine in humans where it is not completely clear if those actions are mediated by adenosine receptors. These studies, in spite of being relevant for caffeine research per se,

${ }^{*}$ Correspondence to: J.A. Ribeiro, Institute of Pharmacology and Neurosciences, Faculty of Medicine and Unit of Neurosciences, Institute of Molecular Medicine, University of Lisbon, Av Prof Egas Moniz, 1649-028 Lisbon, Portugal. Tel.: +351 217985183; E-mail: jaribeiro@fm.ul.pt. were considered out of the scope of the present work. For more detailed analysis of the actions of caffeine in humans, namely cognition, dementia, and Alzheimer's disease, the reader may refer to other papers published in the present issue.

The broad caffeine intake in common beverages, together with the impact of xanthines on biomedical research, prompted many studies that focus on specific caffeine effects rather than using it as a tool to antagonize adenosine receptors (ARs) [1-3]. Caffeine is mainly present in coffee, which also contains trace amounts of theophylline, but no theobromine. Tea is another common source of caffeine. As a pharmacological tool, caffeine is not very useful since its affinity for ARs is low and its selectivity towards the different ARs is also very poor. Caffeine is an antagonist of all subtypes of ARs, and chronic or acute intake of caffeine may affect ARs in different and even opposite ways. Having similar affinity for A1 and A2A Rs [1], acute caffeine actions at a given brain area will reflect the preponderant AR activation in that area, since most of the adenosinergic tonus are exerted through that receptor. 


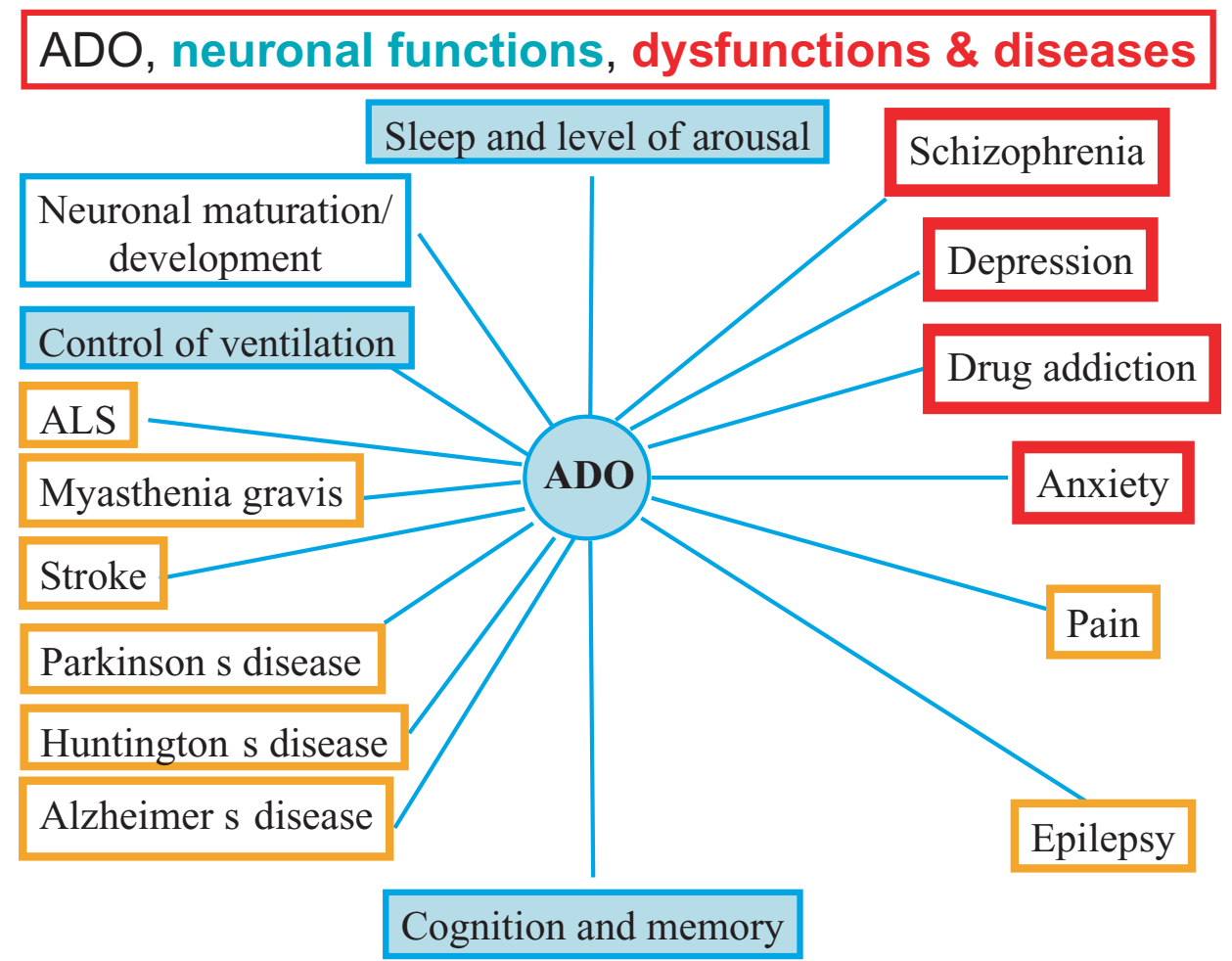

Fig. 1. Actions proposed for adenosine on the central nervous system, including on brain functions, dysfunctions and diseases. As caffeine is a non-selective adenosine antagonist and crosses easily the blood brain barrier, it is likely that the caffeine effects on these adenosine receptors mirror those caused by adenosine actions. For further details see Sebastião and Ribeiro, 2009 - Handbook of Experimental Pharmacology, 193, 471-534.

Besides the high affinity $\mathrm{A} 1$ and $\mathrm{A} 2 \mathrm{~A}$ receptors, the cloned adenosine receptors also include the high affinity $\mathrm{A} 3$ receptor, and the low affinity $\mathrm{A} 2 \mathrm{~B}$ receptor. Other entities have been proposed based on functional and/or binding studies (e.g., an atypical A2A receptor in the rat hippocampus [4]; the $\mathrm{A} 3$ receptor in the frog motor nerve endings [5]). The first proposal for the existence of an A3 AR was based upon pharmacological characteristics, namely high affinity for agonists and xanthine sensitivity [5]. Cloning and cellular expression of the rat $\mathrm{A} 3 \mathrm{AR}$ [6] challenged these criteria since the rat A3 receptor is xanthine-insensitive and has low agonist affinity. Cloning and expression of the human A3 $A R$ [7] reversed the situation again since the human A3 $\mathrm{AR}$ is xanthine sensitive and is a high affinity receptor for A3 AR ligands. Although research on the relevance of the A3 AR under pathological conditions is gaining progressive interest, these receptors are poorly expressed in the brain and studies involving them on the actions of caffeine are scarce. Therefore, we decided not to discuss this aspect in the present review.

Adenosine is ubiquitously present in all cells, with receptors distributed in all brain cells; any imbalance of such a widespread system is expected to lead to neurological dysfunctions/diseases (see Fig. 1). When acting as an AR antagonist, caffeine is doing the opposite of adenosine receptors activation, whenever the levels of endogenous adenosine are tonically activating receptors. So caffeine, like adenosine, can potentially exert effects on all brain areas, providing that endogenous adenosine is tonically activating its receptors. As a result of its psychoactive effects, caffeine is considered by some religions (e.g., Mormons, Adventists, Hindus), along with alcohol, nicotine, and other drugs, to cloud the mind and over-stimulate the senses.

In 1819 the German chemist Friedrich Ferdinand Runge isolated caffeine at the behest of Johann Wolfgang von Goethe. As in the work 'Faust' by Goethe, the soul of Faust has been sold to the devil in exchange for 'jeunesse', it appears that Goethe was anticipating, in almost 200 years, the use of caffeine to treat diseases that predominate during aging, such as neurodegenerative diseases.

The structure of caffeine was elucidated near the end of the 19th century by Hermann Fischer, and it is similar to that of adenosine. Caffeine is metabolized in 


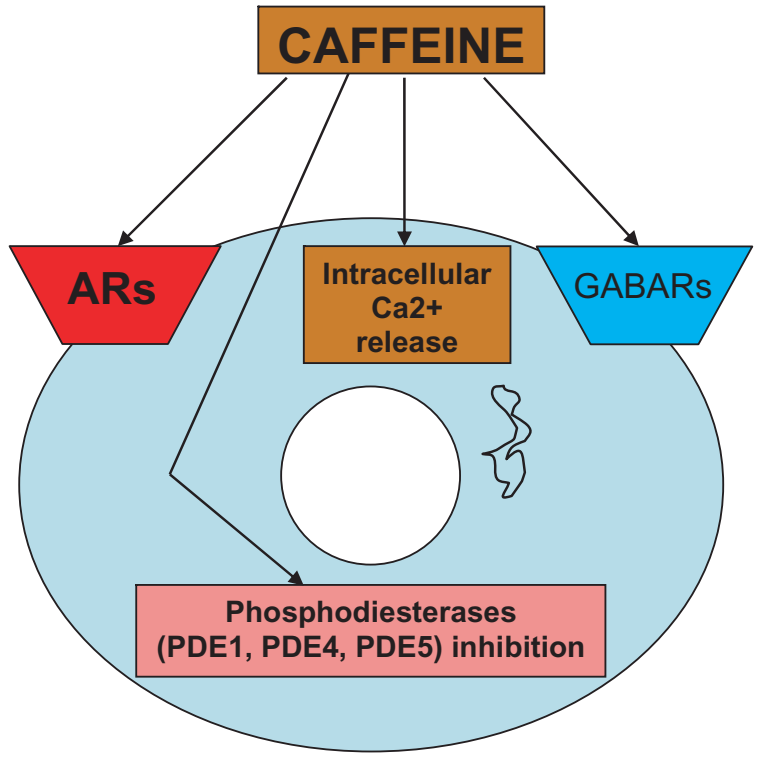

Fig. 2. Sites/mechanisms of action of caffeine. ARs: adenosine receptors. GABARs: GABA receptors.

the liver by the cytochrome P450 oxidase enzyme system into three dimethylxanthines: paraxanthine, which increases lipolysis, leading to elevated glycerol and free fatty acid levels in the blood plasma; theobromine, which dilates blood vessels and increases urine volume; and theophylline, which relaxes smooth muscles of the bronchi, and is used to treat asthma. The therapeutic dose of theophylline, however, is many times greater than the amount resulting from caffeine metabolism taken in non-toxic amounts. Each of those xanthines is further metabolized and then excreted into the urine. For an extensive review including consumption and metabolism of caffeine, see [2].

Adenosine is able to regulate synapses through tuning and fine-tuning. Tuning synapses occurs when adenosine, by activating its receptors, is controlling, e.g. the release of neurotransmitters, by interfering with $\mathrm{Ca}^{2+}$ or other mechanisms directly related to neurotransmitter release [8]. In the case of fine-tuning, adenosine is interfering with receptors for other neuromodulators [9]. Besides AR antagonism, xanthines, including caffeine, have other biological actions (see Fig. 2), such as 1) inhibition of phosphodiesterases (PDEs) (e.g., PDE1, PDE4, PDE5). These effects (up to $40 \%$ inhibition of phosphodiesterases), according to Daly (2007) [1], are observed in concentrations well below those that cause toxic effects. In relation to PDE inhibition, it is interesting to note that caffeine, being a PDE5 inhibitor, operates through a mechanism also used by sildenafil, which is a vasodilator, via selective
PDE5 inhibition. So, the potential effects related to these actions need to be investigated to see whether consequent vasodilation might contribute to net caffeine effects. 2) Promotion of calcium release from intracellular stores. Application of caffeine-halothane contracture test in the diagnosis of malignant hyperthermia is an example of application of this effect. 3) Interfering with GABA-A receptors [1]. According to Daly [1], caffeine analogues can be developed to target any of these mechanisms rather than ARs, and this may be explored therapeutically [1]. However, in the case of caffeine, the effects seen at very low doses, achieved during normal human consumption, are mostly due to AR antagonism [2]. Because of its safety, its ability to antagonize ARs and to readily cross the blood brain barrier, caffeine has therapeutic potential in central nervous system dysfunctions (see below and Fig. 1). Adverse effects of caffeine may include anxiety, hypertension, drug interactions, and withdrawal symptoms [1]. Caffeine improves cognition [1]; however, it also affects sleep [3]. Moreover, a relationship between adenosine A2A ARs and genetic variability in caffeine metabolism associated with habitual caffeine consumption, has been proposed [10], which provides a biological basis for caffeine consumption. In that study, persons with the ADORA2A TT genotype were significantly more likely to consume less caffeine than carriers of the $\mathrm{C}$ allele.

The therapeutic or adverse effects of caffeine are considerably different, depending on whether it is administered chronically or acutely. For example, chronic caffeine intake, which increases plasma concentrations of adenosine [11], may be neuroprotective. This is in contrast with the consequences of acutely antagonizing A1 ARs [12]. Chronic AR antagonism with caffeine may also influence cognition and motor activity in a way that resembles the acute effects of AR agonists [13]. Such opposed actions of chronic versus acute treatment not only have important implications in the development of xanthine- based compounds as therapeutic agents, but also constitute a frequently confounding parameter for research. Up-regulation of A1 ARs after chronic AR antagonism with xanthines occurs, but A2A AR levels apparently do not change. In addition there are changes in the levels of receptors for neurotransmitters with chronic administration of xanthines, namely a marked decrease in $\beta$-adrenergic receptors and an increase in 5-HT and GABA-A receptors [13]. The increased expression of A1 ARs in response to chronic antagonism of ARs by caffeine, as compared with A2A ARs, may lead to a shift in the A1/A2A AR balance 
after prolonged caffeine intake [3]. Moreover, chronic caffeine treatment may lead to modifications in the function of the A1R-A2AR heteromer and this may, in part, be the scientific basis for the strong tolerance to the psychomotor effects of chronic caffeine [14]. Alteration of astrocytogenesis via A2A AR blockade during brain development has been reported [15], raising the possibility that postnatal caffeine treatment could have long-term consequences on brain function, and therefore care should be taken during breast feeding.

\section{Tolerance/Withdrawal}

Tolerance develops very quickly, after heavy doses, e.g. tolerance to sleep disruption (400 mg of caffeine 3 times a day for 7 days), tolerance to subjective effects of caffeine (300 mg 3 times per day for 18 days), and withdrawal symptoms, including inability to concentrate, headache, irritability, drowsiness, insomnia, and pain in the stomach, upper body, and joints (within 12 to 24 hours after discontinuation of caffeine intake, peak being at roughly 48 hours, and usually lasting from one to five days, see Fredholm et al. [2]). This is the time required for the number of adenosine receptors in the brain to revert to "normal" levels. Analgesics, such as aspirin, can relieve the pain withdrawal symptoms, as can a small dose of caffeine [1]. Overuse and dependency occurs after consumption of caffeine in large amounts, and in particular over extended periods of time, inducing caffeinism. Caffeinism combines caffeine dependency with a wide range of unpleasant physical and mental conditions including nervousness, irritability, anxiety, tremulousness, muscle twitching, hyperreflexia, insomnia, headaches, respiratory alkalosis, and heart palpitations. Caffeine increases production of stomach acid; high usage over time can lead to peptic ulcers, erosive esophagitis, and gastroesophageal reflux disease.

The influence of caffeine-adenosine receptor interactions upon brain functions and dysfunctions will be discussed below.

\section{ANXIETY}

Caffeine is well known to promote anxious behaviour in humans and animal models, and can precipitate panic attacks [16]. It is of interest that patients suffering from panic disorder, a serious form of anxiety disorder, appear to be particularly sensitive to small amounts of caffeine [17]. It is, however, worthwhile to note that chronic and acute caffeine consumption may lead to quite different consequences with respect to the function of ARs [18,19]. Short-term anxiety-like effect of caffeine in mice might not be related solely to the blockade of A1 and A2A ARs, since it is not shared by selective antagonists of each receptor [20]. In contrast, anxiolytic effects of xanthine derivatives containing an arylpiperazine moiety have been reported, but this is most probably related to agonist activity at serotonin receptors rather than antagonism of adenosine receptors [1].

The possibility that drugs which facilitate A1 ARmediated actions could be effective for anxiety was supported by the observations that A1 AR agonists have anxiolytic actions in rodents [20,21]. The inhibitory action of A1 ARs on the nervous system, together with the identification of cross-talk mechanisms between benzodiazepines and ARs [22] and transporters [23], soon suggested that adenosine could mediate the anxiolytic action of several centrally active drugs [24]. Accordingly, A1 AR KO mice showed increased anxietyrelated behaviour [25], but this also holds true for A2A AR KO mice [26]. A1 and A2A ARs are involved in benzodiazepine withdrawal signs. In mice, these signs of withdrawal are manifested by increased seizure susceptibility, and agonists of A1 ARs [27] or A2A ARs [28] attenuate them. The potential of A1 AR agonists to reduce the anxiogenic effects during ethanol withdrawal have also been suggested [29]. The caffeine-induced anxiety disorder, which can result from long-term excessive caffeine intake, can mimic organic mental disorders, such as panic disorder, generalized anxiety disorder, bipolar disorder, or even schizophrenia. Caffeine-intoxicated people might be misdiagnosed and unnecessarily medicated when the treatment for caffeine-induced psychosis would simply be to stop further caffeine intake. Other adverse effects of caffeine besides anxiety, sleep disorders, withdrawal symptoms and hypertension, include drug interactions [1].

A significant association between self-reported anxiety after caffeine administration and two linked polymorphisms of the A2A AR gene has been reported [30]. Furthermore, evidence for a susceptibility locus for panic disorder, either within the A2A AR gene or in a nearby region of chromosome 22, was reported [31,32]. This positive association between A2A AR gene polymorphism and panic disorder may, however, not occur in the Asian population [33] suggesting an ethnicitydependent association. 


\section{SLEEP}

Most studies on ARs and sleep regulation in humans rely upon consequences of caffeine ingestion by human volunteers, and it is now widely accepted that caffeine prolongs wakefulness by interfering with the key role of adenosine upon sleep homeostasis [34]. In a review on the role of adenosine upon sleep regulation, PorkkaHeiskanen et al. [35] proposed adenosine as a sleeping factor and hypothesized that adenosine works as a neuroprotector against energy depletion. In the critical arousal area (basal forebrain), extracellular adenosine levels start to rise in response to prolonged neuronal activity during wakeful periods. This increase leads to a decrease in neuronal activity, and sleep is induced before the energy balance, in the whole brain, is affected. Microdialysis measurements performed in freely moving cats showed an increase in the concentrations of adenosine during spontaneous wakefulness, and adenosine transport inhibitors mimicked the sleepwakefulness profile occurring after prolonged wakefulness [36]. In contrast, AR antagonists, like caffeine, increase wakefulness. Prolonged wakefulness induces signs of energy depletion in the brain, which causes facilitation of sleep [37]. Molecular imaging showed that there is A1 receptor upregulation in cortical and subcortical brain regions after prolonged wakefulness in humans [38]. Adenosinergic mechanisms contribute to individual differences associated with sleep deprivation sensitivity in humans [39]. Furthermore, a genetic variation in the adenosine A2A AR gene may contribute to individual sensitivity to the effects of caffeine on sleep [40].

It is well documented that $\mathrm{A}_{1} \mathrm{ARs}$ are involved in sleep regulation by inhibiting ascending cholinergic neurons of the basal forebrain [41]. However, more recent studies, which include experiments with $\mathrm{A} 2 \mathrm{~A}$ and A1 AR KO mice, indicate that A2A ARs (most probably localized in the ventrolateral preoptic area of the hypothalamus) also play a crucial role in the sleep-promoting effects of adenosine and the arousalenhancing effects of caffeine [42]. These studies suggest that A2A AR antagonists may represent a novel approach as potential treatments for narcolepsy and other sleep-related disorders [43]. Adenosine A2A ARs in the pontine reticular formation promote acetylcholine release, rapid eye movement (REM) and non-REM sleep in mice. This effect on non-REM sleep is probably due to A2A AR-induced enhancement of GABAergic inhibition of arousal promoting neurons [44]. In addition to its action in the basal forebrain, adeno- sine exerts its sleep-promoting effect in the lateral hypothalamus by A1 AR-mediated inhibition of hypocretin/orexin neurons $[45,46]$. According to the American Psychiatric Association (APA), the caffeine-induced sleep disorder is sufficiently severe to warrant clinical attention.

In summary, the two high affinity ARs, the A1 and the A2A ARs affect multiple mechanisms in several brain areas involved in regulation of sleep and arousal. Therefore, the influences of caffeine upon sleep felt by many humans, and as mentioned above, also documented in controlled studies in healthy volunteers, can be attributed to both A1 and A2A AR blockade. Chronic caffeine consumption may alter AR function and the A1/A2A AR balance, and as a consequence influences the involvement of both ARs upon sleep.

\section{COGNITION, LEARNING, AND MEMORY}

Endogenous adenosine, through A1 ARs, inhibits long-term synaptic plasticity phenomena, such as long term potentiation (LTP) [47], long term depression (LTD), and depotentiation [48]. In accordance, A1 AR antagonists have for a long time been proposed to treat memory disorders [49]. Cognitive effects of caffeine are mostly due to its ability to antagonise adenosine A1 ARs in the hippocampus and cortex, the brain areas mostly involved in cognition, but as discussed in detail [2], positive actions of caffeine on information processing and performance might also be attributed to improvement of behavioural routines, arousal enhancement and sensorimotor gating, and these actions may be not solely related to A1 receptor function (see below). Theophylline enhances spatial memory performance only during the light period, which is the time of sleepiness in rats [50]. Independently of the processes used by caffeine or theophylline to improve cognition, there is a consensus that the beneficial effects most of us feel after a few cups of coffee or tea are due to the actions of these psychoactive substances upon ARs. Recent evidence that blockade of A1 receptors improves cognition came from a study using a mixed A1/A2A receptor antagonist, ASP5854 [51]. This orally active drug could reverse scopolamine-induced memory deficits in rats, whereas a specific adenosine A2A AR antagonist, KW-6002, did not. Reduced A2A AR activation may also be relevant for cognitive improvements since A2A AR KO mice have improved spatial recognition memory [52]. Accordingly, over-expression of A2A ARs leads to memory deficits [53]. 
There is the possibility that chronic intake of caffeine during one's lifetime might protect from cognitive decline associated with aging. Elderly women who drank relatively large amounts of coffee over their lifetimes have better performances on memory and other cognitive tests than non-drinkers [54]. A case - control study was specifically designed to evaluate if chronic intake of caffeine might be related to a lower risk of Alzheimer's disease [55], the most common form of dementia. Levels of caffeine consumption in the 20 years that preceded the diagnosis in patients were compared with those taken by age- and sex-matched controls with no signs of cognitive impairment. Data analysis showed that caffeine intake was inversely associated with the risk of Alzheimer's disease and that this association was not explained by several possible confounding variables related to habits and medical disorders [55]. This was confirmed in a larger scale study (4,197 women and 2,820 men) with similar objectives, showing that the psychostimulant properties of caffeine appear to reduce cognitive decline in aged women without dementia [56].

Long-term protective effects of dietary caffeine intake were also shown in a controlled longitudinal study involving a transgenic murine model of Alzheimer's disease. Caffeine was added to the drinking water of mice between 4 and 9 months of age, with behavioural testing done during the final 6 weeks of treatment; the results revealed that moderate daily intake of caffeine may delay or reduce the risk of cognitive impairment in these mice [57]. Amnesia can be induced experimentally in mice by central administration of beta-amyloid peptides, a process that involves cholinergic dysfunction [58]. Acute intravenous administration of caffeine or A2A AR antagonists affords protection against beta amyloid-induced amnesia [59]. These acute effects of A2A AR blockade are somehow unexpected because A2A ARs are known to facilitate cholinergic function mainly in the hippocampus [60], and therefore, either adenosine A2A AR agonists or A1 AR antagonists, which prevent A1 AR-mediated inhibition of acetylcholine release, were more likely expected to be cognitive enhancers. Indeed, the most widely used drugs in Alzheimer's disease are directed towards an increase in cholinergic function by inhibiting acetylcholinesterase [61]. These apparent discrepancies point toward the need of more basic research to understand the biological basis and the potential benefit for the emerging adenosine-based therapies for Alzheimer's disease. It is interesting to note the very recent reports by Arendash's group on caffeine protec- tion in Alzheimer's disease transgenic mice [62,63]. In a very recent study [64] it has been shown that human coffee drinking at midlife is associated with a decreased risk of dementia/AD later in life. This finding further supports possibilities for prevention of dementia/AD.

\section{PARKINSON'S DISEASE}

A significant association between higher caffeine intake and lower incidence of Parkinson's disease was reported some years ago [65]. Moreover, the beneficial effects of caffeine in Parkinson's disease patients was also reported [66]. Furthermore, caffeine administered before levodopa may improve its pharmacokinetics in some patients with Parkinson's disease [67].

Caffeine has well-known stimulatory actions upon locomotion due to the antagonism of A2A and A1 ARs in the striatum [3], and in most animal models of Parkinson's disease, antagonizing A2A ARs attenuates some disease symptoms, which has been matter of several reviews published as proceedings of a meeting on the topic [68-71]. So, we will highlight a point that is less focused, which concerns interactions between adenosine and neurotrophic factors. The putative role of the neurotrophic factor, GDNF, in slowing or halting disease progression through facilitation of neuronal survival [72], and the facilitatory action of A2A ARs upon GDNF actions in striatal dopaminergic nerve endings [73], raise the need of great caution when blocking A2A ARs in the early phases of Parkinson's disease. If trophic GDNF actions on dopaminergic neurons will also prove to be dependent upon co-activation of A2A ARs, as it has been observed in relation to fast synaptic actions of this neurotrophic factor [73], it is possible that blockade of A2A ARs will be deleterious during a window of time when it is possible to rescue neurons with trophic support.

Another relevant consideration is related to the recent finding [74] that deep brain stimulation, a procedure now used to reduce tremor in Parkinson's disease patients, involves the release of considerable amounts of ATP with its subsequent extracellular metabolism to adenosine. Activation of A1 ARs by adenosine during this procedure is an essential step to reduce tremor and control spread of excitability, thereby reducing the side effects of deep brain stimulation. However, since A2A ARs are expressed in thalamic areas, it may be expected that A2A ARs are also activated during deep brain stimulation. A2A receptors attenuate A1 receptor functioning [75]. Furthermore, they attenuate D2 
dopaminergic responses [3]. Thus, in late stages of the disease, where it is desirable to prevent A2A ARmediated inhibition of dopamine $\mathrm{D} 2$ receptor function, the use of an A2A AR antagonist in combination with deep brain stimulation may be beneficial.

\section{HUNTINGTON'S DISEASE}

The role played by ARs in Huntington's disease was recently reviewed and discussed [76]. The complexity inherent to a genetically - based, slowly progressing neurodegenerative disease, the different experimental models which are very frequently non-chronic or subchronic models, as well as changes in receptor levels due to cell loss or to prolonged drug administration, give an apparent contradictory picture on the AR involvement in this disease. The pre - versus postsynaptic localization of ARs, in particular of A2A ARs, which have highly distinct roles in striatal function according to their synaptic localization, may also contribute to conflicting neuroprotective/neurotoxic consequences of AR manipulation [77]. Indeed, A1 AR agonists [78], A2A AR agonists [79], as well as A2A $\mathrm{AR}$ antagonists [79], are all able to influence diverse symptoms in experimental models of Huntington's disease. For a detailed discussion of the causes for this conflicting evidence see [76].

Another aspect that applies to all neurodegenerative diseases, and that may be particularly relevant in the case of Huntington's disease, is related to loss of neurotrophic support. Huntington's disease is caused by a mutation in a protein named huntingtin that in its mutated form is neurotoxic. It happens that wild-type huntingtin up-regulates transcription of BDNF [80], and decreased BDNF levels may be an initial cause of neuronal death in this disease. A2A AR activation can facilitate or even trigger BDNF actions in the brain [76, 81-83], pointing toward the possibility that A2A AR activation, at least in the early stages of the disease, may rescue striatal neurons from death due to diminished trophic support by BDNF. It is worth noting that A2A ARs have a dual action in Huntington's disease [76]. The ability of A2A ARs to facilitate actions of BDNF, which is clearly deficient in this neurodegenerative disease [84], is most likely part of the positive influences of A2A ARs against the disease.

\section{EPILEPSY}

There are several clinical reports on caffeine or theophylline intake and seizure susceptibility [86,87], but surprisingly, no mention is made of the main cause of seizure induction by these drugs, i.e., AR antagonism.

Indeed, after the initial observation that adenosine has anticonvulsant actions [87], the therapeutic potential of adenosine related compounds in epilepsy was immediately pointed out [88], and it is now widely accepted that adenosine is an endogenous anticonvulsant, an action mediated by inhibitory A1 ARs that restrain excessive neuronal activity. Other ARs are, however, involved in seizure control, though their role is most frequently related to exacerbation of seizures. The influence of A3 and A2 ARs on GABAA receptor stability has been recently suggested [89], based on the observation that A3 or A2B AR antagonists, acutely applied to oocytes transfected with human GABAA receptors, reduce rundown of GABAA currents. A2A ARs, by promoting neuronal excitability, may also increase seizure susceptibility. Indeed, A2A ARs KO mice are less sensitive to pentylenetetrazol-induced seizures [90].

It has been shown that A1 AR activation by locally released adenosine is an efficient way to keep an epileptic focus localized [91]. Therefore, attention is now focused on the development of biocompatible materials for adenosine-releasing intrahippocampal implants [92]. In line with the evidence for the antiepileptic role of A1 ARs, A1 AR KO mice are more susceptible to seizures and develop lethal status epilepticus after experimental traumatic brain injury [93]. There are, however, limitations in the use of A1 AR agonists as anticonvulsant drugs due to their pronounced peripheral side effects like cardiac asystole, as well as central side effects like sedation [94]. A possibility would be the use of partial agonists, which are more likely to display tissue selectivity. A N6,C8-disubstituted adenosine derivative with low efficacy towards A1 AR activation in whole brain membranes but with high efficacy as an inhibitor of hippocampal synaptic transmission was identified [95]. Another approach that has been more intensely explored is the use of compounds that increase the extracellular concentrations of adenosine. This has been attempted with adenosine kinase (AK) inhibitors, which showed beneficial effects in animal models of epilepsy, and an improved preclinical therapeutic index over direct acting AR agonists [96]. An even more refined approach was the local reconstitution of the inhibitory adenosinergic tone by intracerebral implantation of cells engineered to release adenosine, 
and this has been done using AK deficient cells [97]. The reverse also holds true, since transgenic mice overexpressing AK in the brain have increased seizure susceptibility [91]. Furthermore, intrahippocampal implants of AK-deficient stem cell-derived neural precursors suppress kindling epileptogenesis [98]. The above evidence suggests that adenosine-augmenting cell and gene therapies may lead to improved treatment options for patients suffering from intractable epilepsy [99].

AK is mostly expressed in astrocytes [100], and overexpression of AK after seizures, with consequent reduced adenosine inhibitory tone, contributes to seizure aggravation [91]. However, release of interleukin6 (IL-6) from astrocytes induces an upregulation of A1 ARs both in astrocytes [101] and neurons [102]. This leads to an amplification of A1 AR function, enhances the response to readily released adenosine, enables neuronal rescue from glutamate-induced death, and protects animals from chemically induced convulsing seizures [102]. Indeed, IL-6 KO mice are more susceptible to seizures and lack the well known seizureinduced up-regulation of A1 ARs [102].

Seizure-induced release of neurotrophic factors, such as BDNF, may have beneficial and aggravating actions upon epilepsy, the beneficial ones being mostly related to promotion of cell survival, the deleterious ones being related to excessive cell proliferation and neuronal sprouting [103]. Adenosine, through A2A $\mathrm{AR}$ activation, triggers and facilitates BDNF actions in neurons $[82,83]$, but the relevance of this interplay for epilepsy remains to be explored.

\section{PAIN/MIGRAINE}

Caffeine makes pain relievers $40 \%$ more effective in alleviating headaches and helps the body to absorb headache medications more quickly, bringing faster relief. Many headache drugs include caffeine in their formula. It is also used with the vasoconstrictor ergotamine in the treatment of migraine and cluster headaches as well as to overcome the drowsiness caused by antihistaminics. It is well established that A2A receptors are potent vasodilators, and therefore the influence of caffeine in migraine probably occurs through A2A receptor antagonism [2]. However, other mechanisms might also coexist. Calcitonin Gene Related Peptide - Receptors (CGRP-R) antagonists are useful in the treatment of migraine, and as CGRP effects on synaptic transmission are greatly enhanced by A2A receptors activation [104], one is tempted to speculate that $\mathrm{A} 2 \mathrm{~A}$ receptor blockade and consequent attenuation of CGRP-R activation might also contribute to the ability of caffeine to alleviate migraine. It is likely that its association with CGRP receptor antagonists, useful to treat migraine, will substantially increase the efficacy of these drugs in the treatment of headache/migraine.

\section{DEPRESSION}

A2A AR KO mice and wild-type mice injected with A2A AR antagonists were found to be less sensitive to 'depressant' challenges than controls [105], suggesting that blockade of adenosine A2A ARs might be an interesting target for the development of antidepressant agents. This antidepressant-like effect of selective A2A AR antagonists is probably linked to an interaction with dopaminergic transmission, possibly in the frontal cortex, since administration of the dopamine D2 receptor antagonist, haloperidol, prevents antidepressantlike effects elicited by selective A2A AR antagonists in the forced swim test (putatively involving cortex), whereas it had no effect on stimulant motor effects of selective A2A AR antagonists (e.g. caffeine, putatively linked to ventral striatum) [106]. Depression is frequently associated to loss of motivation and psychomotor slowing. In this context, it is interesting to note that A2A AR in the nucleus accumbens appear to regulate effort-related processes, an action that could be related to modulation of the ventral striatopallidal pathway [107].

Besides A2A ARs, A1 ARs are also probably involved in the antidepressant-like effect of adenosine [108], which may be consequence of interactions with the opioid system [109].

It is worthwhile to note that deep brain stimulation, now widely used by neurosurgeons to treat tremor and other movement disorders, as well as a number of psychiatric diseases including obsessive-compulsive disorders and depression, produces its effects by inducing the release of ATP which is subsequently converted extracellularly to adenosine [74,110].

Results from clinical and basic studies have demonstrated that stress and depression decrease BDNF expression and neurogenesis, leading to the neurotrophic hypothesis of depression [111,112]. How adenosine A2A AR-dependent facilitation of BDNF actions on hippocampal synapses, namely enhancement of synaptic transmission [81] and enhancement of synaptic plasticity [83], may contribute to some antidepressive actions of adenosine remains to be established. 


\section{SCHIZOPHRENIA}

No study so far has directly evaluated the influence of caffeine in schizophrenia, but there is growing evidence that adenosine dysfunction may contribute to the neurobiological and clinical features of schizophrenia [113]. Indeed, adenosine, via activation of A1 and A2A ARs, is uniquely positioned to influence glutamatergic and dopaminergic neurotransmission, two neurotransmitter systems that are mostly affected by the disease. It is possible that an adenosine inhibitory deficit may emerge, resulting in reduced control of dopamine activity and increased vulnerability to excitotoxic glutamate action in the mature brain. Interactions between A2A ARs and D2 receptors allow further opportunity for mutual modulation between the adenosine and dopamine systems [114]. These mechanisms could provide a rationale for an antipsychoticlike profile of AR agonists, in particular A2A AR agonists, to promote a reduction in $\mathrm{D} 2$ receptor signaling [114], and A1 AR agonists to promote a reduction in dopamine release [113]. Indeed, dipyridamole, a well known inhibitor of adenosine transporters, and therefore an enhancer of extracellular adenosine levels, may be of some therapeutic interest in schizophrenic patients [115].

Reduced NMDA receptor function may contribute to the cognitive and negative symptoms of schizophrenia [116]. The relationships between adenosine and NMDA receptor function are complex and may operate in opposite ways. Thus, NMDA receptor activation induces adenosine release $[117,118]$, and therefore NMDA receptor hypofunction may induce a decrease in adenosine-mediated actions. On the other hand, NMDA receptor activation suppresses neuronal sensitivity to adenosine [119]. In addition, both A1 [120] and A2A ARs [121] can influence NMDA receptor functioning, both receptors being able to inhibit NMDA currents in different brain areas

\section{CONCLUSION}

Adenosine builds its influence on neuronal communication via fine-tuning, 'synchronizing' or 'desynchronizing' receptor activation [9]. On the other hand, abnormal neural synchronization is considered to be central to and the underlying basis for several neurological diseases such as epilepsy, schizophrenia, autism, Alzheimer's disease, and Parkinson's disease [122]. It is well established that adenosine is involved in brain homeostasis, and recently proposed to be crucial to the effects of deep brain stimulation [74], which aims to affect neuronal 'synchronization' and, therefore, influence several psychiatric and neurodegenerative diseases. One is, therefore, tempted to propose that adenosine works as a sort of "universal modulator" or a "maestro", being the main molecule involved in coordinating and controlling the synchronization of the release and actions of many synaptic mediators. These actions of adenosine are operated by high affinity A1 and A2A receptors, and caffeine affects both. Chronic caffeine may up-regulate adenosine receptors and exacerbate adenosine levels and some adenosine actions in the brain.

In conclusion, targeting approaches that involve abnormal synchronization, namely ARs, will enhance our possibilities to interfere in and/or correct brain dysfunctions. An efficient way may be through the use of the universally consumed substance caffeine.

\section{ACKNOWLEDGMENTS}

The work in the authors' laboratory is supported by research grants from Fundação para a Ciência e Tecnologia (FCT), Gulbenkian Foundation and European Union (COST B30).

Authors' disclosures available online (http://www.jalz.com/disclosures/view.php?id=212).

\section{REFERENCES}

[1] Daly JW (2007) Caffeine analogs: biomedical impact. Cell Mol Life Sci 64, 2153-2169.

[2] Fredholm BB, Bättig K, Holmén J, Nehlig A, Zvartau EE (1999) Actions of caffeine in the brain with special reference to factors that contribute to its widespread use. Pharmacol Rev 51, 83-133.

[3] Ferré S (2008) An update on the mechanisms of the psychostimulant effects of caffeine. J Neurochem 105, 1067-1079.

[4] Cunha RA, Constantino, MD \& Ribeiro JA (1999) G-protein coupling of CGS 21680 binding sites in the rat hippocampus and cortex is different from that of adenosine $\mathrm{A}_{1}$ and striatal $\mathrm{A}_{2 A}$ receptors. Naunyn Schmiedberg's Arch Pharmacol 359, 295-302.

[5] Ribeiro JA, Sebastião AM (1986) Adenosine receptors and calcium: basis for proposing a third (A3) adenosine receptor. Prog Neurobiol 26, 179-209.

[6] Zhou QY, Li C, Olah ME, Johnson RA, Stiles GL, Civelli O (1992) Molecular cloning and characterization of an adenosine receptor: the A3 adenosine receptor. Proc Natl Acad Sci USA 89, 7432-7436.

[7] Salvatore CA, Jacobson MA, Taylor HE, Linden J, Johnson RG (1993) Molecular cloning and characterization of the human A3 adenosine receptor. Proc Natl Acad Sci USA 90, 10365-10369. 
[8] Ribeiro JA (1994) Purinergic inhibition of neurotransmitter release in the central nervous system. Pharmacol Toxicol 77, 299-305.

[9] Sebastião AM, Ribeiro JA (2000) Fine-tuning neuromodulation by adenosine. Trends Pharmacol Sci 21, 341-346.

[10] Cornelis MC, El-Sohemy A, Campos H (2007) Genetic polymorphism of the adenosine $\mathrm{A} 2 \mathrm{~A}$ receptor is associated with habitual caffeine consumption. Am J Clin Nutr 86, 240-244.

[11] Conlay LA, Conant JA, deBros F, Wurtman R (1997) Caffeine alters plasma adenosine levels. Nature 389, 136.

[12] de Mendonça A, Sebastião AM, Ribeiro JA (2000) Adenosine: does it have a neuroprotective role after all? Brain Res Rev 33, 258-274.

[13] Jacobson KA, von Lubitz D KJE, Daly JW, Fredholm BB (1996) Adenosine receptor ligands: differences with acute versus chronic treatment. Trends Pharmacol Sci 17, 108-113.

[14] Ciruela F, Casadó V, Rodrigues RJ, Luján R, Burgueño J, Canals M, Borycz J, Rebola N, Goldberg SR, Mallol J, Cortés A, Canela EI, López-Giménez JF, Milligan G, Lluis C, Cunha RA, Ferré S, Franco R (2006) Presynaptic control of striatal glutamatergic neurotransmission by adenosine A1-A2A receptor heteromers. J Neurosci 26, 2080-2087.

[15] Desfrere L, Olivier P, Schwendimann L, Verney C, Gressens P (2007) Transient inhibition of astrocytogenesis in developing mouse brain following postnatal caffeine exposure. Pediatr Res 62, 604-609.

[16] Klein E, Zohar J, Geraci MF, Murphy DL, Uhde TW (1991) Anxiogenic effects of $\mathrm{m}-\mathrm{CPP}$ in patients with panic disorder: comparison to caffeine's anxiogenic effects. Biol Psychiatry 30, 973-984.

[17] Boulenger JP, Uhde TW, Wolff EA 3rd, Post RM (1984) Increased sensitivity to caffeine in patients with panic disorders. Preliminary evidence. Arch Gen Psychiatry 41, 1067-1071.

[18] Boulenger JP, Patel J, Post RM, Parma AM, Marangos PJ (1983) Chronic caffeine consumption increases the number of brain adenosine receptors. Life Sci 32, 1135-1142.

[19] El Yacoubi M, Ledent C, Parmentier M, Costentin J, Vaugeois JM (2000) The anxiogenic-like effect of caffeine in two experimental procedures measuring anxiety in the mouse is not shared by selective $\mathrm{A}(2 \mathrm{~A})$ adenosine receptor antagonists. Psychopharmacology (Berl) 148, 153-163.

[20] Florio C, Prezioso A, Papaioannou A, Vertua R (1998) Adenosine A1 receptors modulate anxiety in CD1 mice. Psychopharmacology (Berl) 136, 311-319.

[21] Jain N, Kemp N, Adeyemo O, Buchanan P, Stone TW (1995) Anxiolytic activity of adenosine receptor activation in mice. Br J Pharmacol 116, 2127-2133.

[22] Boulenger JP, Patel J, Marangos PJ (1982) Effects of caffeine and theophylline on adenosine and benzodiazepine receptors in human brain. Neurosci Lett 30, 161-166.

[23] Bender AS, Phillis JW, Wu PH (1980) Diazepam and flurazepam inhibit adenosine uptake by rat brain synaptosomes. J Pharm Pharmacol 32, 293-294.

[24] Phillis JW, Wu PH (1982) Adenosine mediates sedative action of various centrally active drugs. Med Hypotheses $\mathbf{9}$, 361-367.

[25] Johansson B, Halldner L, Dunwiddie TV, Masino SA, Poelchen W, Giménez-Llort L, Escorihuela RM, FernándezTeruel A, Wiesenfeld-Hallin Z, Xu XJ, Hrdemark A, Betsholtz C, Herlenius E, Fredholm BB (2001) Hyperalgesia, anxiety, and decreased hypoxic neuroprotection in mice lacking the adenosine A1 receptor. Proc Natl Acad Sci USA 98, 9407-9412.

[26] Ledent C, Vaugeois JM, Schiffmann SN, Pedrazzini T, El
Yacoubi M, Vanderhaeghen JJ, Costentin J, Heath JK, Vassart G, Parmentier M (1997) Aggressiveness, hypoalgesia and high blood pressure in mice lacking the adenosine A2a receptor. Nature 388, 674-678.

[27] Listos J, Malec D, Fidecka S (2005) Influence of adenosine receptor agonists on benzodiazepine withdrawal signs in mice. Eur J Pharmacol 523, 71-78.

[28] Listos J, Talarek S, Fidecka S (2008) Adenosine receptor agonists attenuate the development of diazepam withdrawalinduced sensitization in mice. Eur J Pharmacol 588, 72-77.

[29] Prediger RD, da Silva GE, Batista LC, Bittencourt AL, Takahashi RN (2006) Activation of adenosine A1 receptors reduces anxiety-like behavior during acute ethanol withdrawal (hangover) in mice. Neuropsychopharmacology 31, 22102220.

[30] Alsene K, Deckert J, Sand P, de Wit H (2003) Association between A2a receptor gene polymorphisms and caffeineinduced anxiety. Neuropsychopharmacology 28, 1694-1702.

[31] Deckert J, Nöthen MM, Franke P, Delmo C, Fritze J, Knapp M, Maier W, Beckmann H, Propping P (1998) Systematic mutation screening and association study of the A1 and A2a adenosine receptor genes in panic disorder suggest a contribution of the A2a gene to the development of disease. Mol Psychiatry 3, 81-85.

[32] Hamilton SP, Slager SL, De Leon AB, Heiman GA, Klein DF, Hodge SE, Weissman MM, Fyer AJ, Knowles JA (2004) Evidence for genetic linkage between a polymorphism in the adenosine $2 \mathrm{~A}$ receptor and panic disorder. Neuropsychopharmacology 29, 558-565.

[33] Lam P, Hong CJ, Tsai SJ (2005) Association study of A2a adenosine receptor genetic polymorphism in panic disorder. Neurosci Lett 378, 98-101.

[34] Landolt HP (2008) Sleep homeostasis: A role for adenosine in humans? Biochem Pharmacol 75, 2070-2079.

[35] Porkka-Heiskanen T, Alanko L, Kalinchuk A, Stenberg D (2002) Adenosine and sleep. Sleep Med Rev 6, 321-332.

[36] Porkka-Heiskanen T, Strecker RE, Thakkar M, Bjorkum AA, Greene RW, McCarley RW (1997) Adenosine: a mediator of the sleep-inducing effects of prolonged wakefulness. Science 276, 1265-1268.

[37] Benington JH, Heller HC (1995) Restoration of brain energy metabolism as the function of sleep. Prog Neurobiol 45, 347360.

[38] Elmenhorst D, Meyer PT, Winz OH, Matusch A, Ermert J, Coenen HH, Basheer R, Haas HL, Zilles K, Bauer A (2007) Sleep deprivation increases A1 adenosine receptor binding in the human brain: a positron emission tomography study. J Neurosci 27, 2410-2415.

[39] Rétey JV, Adam M, Gottselig JM, Khatami R, Dürr R, Achermann P, Landolt HP (2006) Adenosinergic mechanisms contribute to individual differences in sleep deprivation-induced changes in neurobehavioral function and brain rhythmic activity. J Neurosci 26, 10472-10479.

[40] Rétey JV, Adam M, Khatami R, Luhmann UF, Jung HH, Berger W, Landolt HP (2007) A genetic variation in the adenosine A2A receptor gene (ADORA2A) contributes to individual sensitivity to caffeine effects on sleep. Clin Pharmacol Ther 81, 692-698.

[41] Basheer R, Strecker RE, Thakkar MM. McCarley RW (2004) Adenosine and sleep-wake regulation. Prog Neurobiol 73, 379-396.

[42] Huang ZL, Qu WM, Eguchi N, Chen JF, Schwarzschild MA, Fredholm BB, Urade Y, Hayaishi O (2005) Adenosine A2A, but not $\mathrm{A} 1$, receptors mediate the arousal effect of caffeine. 
Nat Neurosci 8, 858-859.

[43] Ferré S, Diamond I, Goldberg SR, Yao L, Hourani SM, Huang ZL, Urade Y, Kitchen I (2007) Adenosine A2A receptors in ventral striatum, hypothalamus and nociceptive circuitry implications for drug addiction, sleep and pain. Prog Neurobiol 83, 332-347.

[44] Coleman CG, Baghdoyan HA, Lydic R (2006) Dialysis delivery of an adenosine A2A agonist into the pontine reticular formation of C57BL/6J mouse increases pontine acetylcholine release and sleep. $J$ Neurochem $96,1750-1759$.

[45] Liu ZW, Gao XB (2007) Adenosine inhibits activity of hypocretin/orexin neurons by the A1 receptor in the lateral hypothalamus: a possible sleep-promoting effect. J Neurophysiol 97, 837-848.

[46] Thakkar MM, Engemann SC, Walsh KM, Sahota PK (2008) Adenosine and the homeostatic control of sleep: effects of A1 receptor blockade in the perifornical lateral hypothalamus on sleep-wakefulness. Neuroscience 153, 875-880.

[47] de Mendonça A, Ribeiro JA (1994) Endogenous adenosine modulates long-term potentiation in the hippocampus. $\mathrm{Neu}$ roscience 62, 385-390.

[48] de Mendonça A, Almeida T, Bashir ZI, Ribeiro JA (1997) Endogenous adenosine attenuates long-term depression and depotentiation in the CA1 region of the rat hippocampus. Neuropharmacology 36, 161-167.

[49] Stone TW, Collis MG, Williams M, Miller LP, Karasawa A, Hillaire-Buys D (1995) Adenosine: some therapeutic applications and prospects. In: Cuello AC, Collier B (Eds.), Pharmacological Sciences: Perspectives for Research and Therapy in the Late 1990s. Birkhäuser Verlag Basel, pp. 303-309.

[50] Hauber W, Bareiss A (2001) Facilitative effects of an adenosine A1/A2 receptor blockade on spatial memory performance of rats: selective enhancement of reference memory retention during the light period. Behav Brain Res $\mathbf{1 1 8}$, 43-52.

[51] Mihara T, Mihara K, Yarimizu J, Mitani Y, Matsuda R, Yamamoto H, Aoki S, Akahane A, Iwashita A, Matsuoka N (2007) Pharmacological characterization of a novel, potent adenosine $\mathrm{A} 1$ and $\mathrm{A} 2 \mathrm{~A}$ receptor dual antagonist, 5-[5-amino-3-(4-fluorophenyl)pyrazin-2-yl]1-isopropylpyridine-2(1H)-one (ASP5854), in models of Parkinson's disease and cognition. J Pharmacol Exp Ther 323, 708-719.

[52] Wang JH, Ma YY, van den Buuse M (2006) Improved spatial recognition memory in mice lacking adenosine A2A receptors. Exp Neurol 199, 438-445.

[53] Giménez-Llort L, Schiffmann SN, Shmidt T, Canela L, Camón L, Wassholm M, Canals M, Terasmaa A, FernándezTeruel A, Tobeña A, Popova E, Ferré S, Agnati L, Ciruela F, Martínez E, Scheel-Kruger J, Lluis C, Franco R, Fuxe K, Bader M (2007) Working memory deficits in transgenic rats overexpressing human adenosine A2A receptors in the brain. Neurobiol Learn Mem 87, 42-56.

[54] Johnson-Kozlow M, Kritz-Silverstein D, Barrett-Connor E, Morton D (2002) Coffee consumption and cognitive function among older adults. Am J Epidemiol 156, 842-850.

[55] Maia L, de Mendonça A. (2002) Does caffeine intake protect from Alzheimer's disease? Eur J Neurol 9, 377-382.

[56] Ritchie K, Carrière I, de Mendonca A, Portet F, Dartigues JF, Rouaud O, Barberger-Gateau P, Ancelin ML (2007) The neuroprotective effects of caffeine: a prospective population study (the Three City Study). Neurology 69, 536-545.

[57] Arendash GW, Schleif W, Rezai-Zadeh K, Jackson EK, Zacharia LC, Cracchiolo JR, Shippy D, Tan J (2006) Caffeine protects Alzheimer's mice against cognitive impairment and reduces brain beta-amyloid production. Neuroscience 142, 941-952.

[58] Maurice T, Lockhart BP, Privat A (1996) Amnesia induced in mice by centrally administered beta-amyloid peptides involves cholinergic dysfunction. Brain Res 706, 181-193.

[59] Dall'Igna OP, Fett P, Gomes MW, Souza DO, Cunha RA, Lara DR (2007) Caffeine and adenosine A(2a) receptor antagonists prevent beta-amyloid (25-35)-induced cognitive deficits in mice. Exp Neurol 203, 241-245.

[60] Cunha RA, Milusheva E, Vizi ES, Ribeiro JA, Sebastião AM (1994) Excitatory and inhibitory effects of A1 and A2A adenosine receptor activation on the electrically evoked $[3 \mathrm{H}]$ acetylcholine release from different areas of the rat hippocampus. J Neurochem 63, 207-214.

[61] Doody RS, Geldmacher DS, Gordon B, Perdomo CA, Pratt RD (2001) Donepezil Study Group Open-label, multicenter, phase 3 extension study of the safety and efficacy of donepezil in patients with Alzheimer disease. Arch Neurol 58, 427-433.

[62] Cao C, Cirrito JR, Lin X, Wang L, Verges DK, Dickson A, Mamcarz M, Zhang C, Mori T, Arendash GW, Holtzman DM, Potter H. (2009) Caffeine suppresses amyloid-beta levels in plasma and brain of Alzheimer's disease transgenic mice. $J$ Alzheimers Dis 17, 681-697.

[63] Arendash GW, Mori T, Cao C, Mamcarz M, Runfeldt M, Dickson A, Rezai-Zadeh K, Tan J, Citron BA, Lin X, Echeverria V, Potter H. (2009) Caffeine reverses cognitive impairment and decreases brain amyloid-beta levels in aged Alzheimer's disease mice. J Alzheimers Dis 7, 661-680.

[64] Eskelinen MH, Ngandu T, Tuomilehto J. Soininen H, Kivipelto $M$ (2009) Midlife coffee and tea drinking and the risk of late-life dementia: a population-based CAIDE study. $J$ Alzheimers Dis 16, 85-91.

[65] Ross GW, Abbott RD, Petrovitch H, Morens DM, Grandinetti A, Tung KH, Tanner CM, Masaki KH, Blanchette PL, Curb JD, Popper JS, White LR (2000) Association of coffee and caffeine intake with the risk of Parkinson disease. JAMA 283, 2674-2679.

[66] Kitagawa M, Houzen H, Tashiro K (2007) Effects of caffeine on the freezing of gait in Parkinson's disease. Mov Disord 22, 710-712.

[67] Deleu D, Jacob P, Chand P, Sarre S, Colwell A (2006) Effects of caffeine on levodopa pharmacokinetics and pharmacodynamics in Parkinson disease. Neurology 67, 897-899.

[68] Chen JF, Sonsalla PK, Pedata F, Melani A, Domenici MR, Popoli P, Geiger J, Lopes LV, de Mendonça A (2007) Adenosine A2A receptors and brain injury: broad spectrum of neuroprotection, multifaceted actions and "fine tuning" modulation. Prog Neurobiol 83, 310-331.

[69] Fredholm BB, Chern Y, Franco R, Sitkovsky M (2007) Aspects of the general biology of adenosine A2A signaling. Prog Neurobiol 83, 263-276.

[70] Morelli M, Di Paolo T, Wardas J, Calon F, Xiao D, Schwarzschild MA (2007) Role of adenosine A2A receptors in parkinsonian motor impairment and 1-DOPA-induced motor complications. Prog Neurobiol 83, 293-309.

[71] Schiffmann SN, Fisone G, Moresco R, Cunha RA, Ferré S (2007) Adenosine A2A receptors and basal ganglia physiology. Prog Neurobiol 83, 277-292.

[72] Peterson AL, Nutt JG (2008) Treatment of Parkinson's Disease with Trophic Factors. Neurotherapeutics 5, 270-280.

[73] Gomes CA, Vaz SH, Ribeiro JA, Sebastião AM (2006) Glial cell line-derived neurotrophic factor (GDNF) enhances 
dopamine release from striatal nerve endings in an adenosine A2A receptor-dependent manner. Brain Res 1113, 129-136.

[74] Bekar L, Libionka W, Tian GF, Xu Q, Torres A, Wang X, Lovatt D, Williams E, Takano T, Schnermann J, Bakos R, Nedergaard M (2008) Adenosine is crucial for deep brain stimulation-mediated attenuation of tremor. Nat Med 14, 1719.

[75] Lopes LV, Cunha RA, Kull B, Fredholm BB, Ribeiro JA (2002) Adenosine A2A receptor facilitation of hippocampal synaptic transmission is dependent on tonic A1 receptor inhibition. Neuroscience 112, 319-329.

[76] Popoli P, Blum D, Martire A, Ledent C, Ceruti S, Abbracchio MP (2007) Functions, dysfunctions and possible therapeutic relevance of adenosine A2A receptors in Huntington's disease. Prog Neurobiol 81, 331-348.

[77] Blum D, Galas MC, Pintor A, Brouillet E, Ledent C, Muller CE, Bantubungi K, Galluzzo M, Gall D, Cuvelier L, Rolland AS, Popoli P, Schiffmann SN (2003) A dual role of adenosine A2A receptors in 3-nitropropionic acid-induced striatal lesions: implications for the neuroprotective potential of A2A antagonists. J Neurosci 23, 5361-5369.

[78] Blum D, Gall D, Galas MC, d'Alcantara P, Bantubungi K, Schiffmann SN (2002) The adenosine A1 receptor agonist adenosine amine congener exerts a neuroprotective effect against the development of striatal lesions and motor impairments in the 3-nitropropionic acid model of neurotoxicity. $J$ Neurosci 22, 9122-9133.

[79] Domenici MR, Scattoni ML, Martire A, Lastoria G, Potenza RL, Borioni A, Venerosi A, Calamandrei G, Popoli P (2007) Behavioral and electrophysiological effects of the adenosine A2A receptor antagonist SCH 58261 in R6/2 Huntington's disease mice. Neurobiol Dis 28, 197-205.

[80] Zuccato C, Ciammola A, Rigamonti D, Leavitt BR, Goffredo D, Conti L, MacDonald ME, Friedlander RM, Silani V, Hayden MR, Timmusk T, Sipione S, Cattaneo E (2001) Loss of huntingtin-mediated BDNF gene transcription in Huntington's disease. Science 293, 493-498.

[81] Diógenes MJ, Fernandes CC, Sebastião AM, Ribeiro JA (2004) Activation of adenosine A2A receptor facilitates brain-derived neurotrophic factor modulation of synaptic transmission in hippocampal slices. J Neurosci 24, 29052913.

[82] Diógenes MJ, Assaife-Lopes N, Pinto-Duarte A, Ribeiro JA, Sebastião AM (2007) Influence of age on BDNF modulation of hippocampal synaptic transmission: interplay with adenosine A2A receptors. Hippocampus 17, 577-585.

[83] Fontinha BM, Diógenes MJ, Ribeiro JA, Sebastião AM (2008) Enhancement of long-term potentiation by brainderived neurotrophic factor requires adenosine $\mathrm{A}(2 \mathrm{~A})$ receptor activation by endogenous adenosine. Neuropharmacology 54, 924-933.

[84] Zuccato C, Cattaneo E (2007) Role of brain-derived neurotrophic factor in Huntington's disease. Prog Neurobiol 81, 294-330.

[85] Kaufman KR, Sachdeo RC (2003) Caffeinated beverages and decreased seizure control. Seizure 12, 519-521.

[86] Mortelmans LJ, Van Loo M, De Cauwer HG, Merlevede K. (2008) Seizures and hyponatremia after excessive intake of diet coke. Eur J Emerg Med 15, 51.

[87] Barraco RA, Swanson TH, Phillis JW, Berman RF (1984) Anticonvulsant effects of adenosine analogues on amygdaloidkindled seizures in rats. Neurosci Lett 46, 317-322.

[88] Dragunow M, Goddard GV, Laverty R (1985) Is adenosine an endogenous anticonvulsant? Epilepsia 26, 480-487.
[89] Roseti C, Martinello K, Fucile S, Piccari V, Mascia A, Di Gennaro G, Quarato PP, Manfredi M, Esposito V, Cantore G, Arcella A, Simonato M, Fredholm BB, Limatola C, Miledi R, Eusebi F (2008) Adenosine receptor antagonists alter the stability of human epileptic GABAA receptors. Proc Natl Acad Sci USA 105, 15118-15123.

[90] El Yacoubi M, Ledent C, Parmentier M, Costentin J, Vaugeois JM (2008) Evidence for the involvement of the adenosine $\mathrm{A}(2 \mathrm{~A})$ receptor in the lowered susceptibility to pentylenetetrazol-induced seizures produced in mice by long-term treatment with caffeine. Neuropharmacology $\mathbf{5 5}$, 35-40.

[91] Fedele DE, Li T, Lan JQ, Fredholm BB, Boison D (2006) Adenosine A1 receptors are crucial in keeping an epileptic focus localized. Exp Neurol 200, 184-190.

[92] Wilz A, Pritchard EM, Li T, Lan JQ, Kaplan DL, Boison D (2008) Silk polymer-based adenosine release: therapeutic potential for epilepsy. Biomaterials 29, 3609-3616.

[93] Kochanek PM, Vagni VA, Janesko KL, Washington CB, Crumrine PK, Garman RH, Jenkins LW, Clark RS, Homanics GE, Dixon CE, Schnermann J, Jackson EK (2006) Adenosine A1 receptor knockout mice develop lethal status epilepticus after experimental traumatic brain injury. J Cereb Blood Flow Metab 26, 565-575.

[94] Dunwiddie TV (1999) Adenosine and suppression of seizures. Adv Neurol 79, 1001-1010.

[95] Lorenzen A, Sebastião AM, Sellink A, Vogt H, Schwabe U, Ribeiro JA, IJzerman AP (1997) Biological activities of N6,C8-disubstituted adenosine derivatives as partial agonists at rat brain adenosine A1 receptors. Eur J Pharmacol 334, 299-307.

[96] McGaraughty S, Cowart M, Jarvis MF, Berman RF (2005) Anticonvulsant and antinociceptive actions of novel adenosine kinase inhibitors. Curr Top Med Chem 5, 43-58.

[97] Güttinger M, Fedele D, Koch P, Padrun V, Pralong WF, Brüstle O, Boison D (2005) Suppression of kindled seizures by paracrine adenosine release from stem cell-derived brain implants. Epilepsia 46, 1162-1169.

[98] Li T, Steinbeck JA, Lusardi T, Koch P, Lan JQ, Wilz A Segschneider M, Simon RP, Brustle O, Boison D (2007) Suppression of kindling epileptogenesis by adenosine releasing stem cell derived brain implants. Brain 130, 1276-1288.

[99] Boison D (2007) Adenosine-based cell therapy approaches for pharmacoresistant epilepsies. Neurodegener Dis 4, 28-33.

[100] Studer FE, Fedele DE, Marowsky A, Schwerdel C, Wernli K, Vogt K, Fritschy J-M, Boison D (2006) Shift of adenosine kinase expression from neurons to astrocytes during postnatal development suggests dual functionality of the enzyme. Neuroscience 142, 125-137.

[101] Biber K, Lubrich B, Fiebich BL, Boddeke HW, van Calker D (2001) Interleukin-6 enhances expression of adenosine $\mathrm{A}(1)$ receptor mRNA and signaling in cultured rat cortical astrocytes and brain slices. Neuropsychopharmacology 24, 86-96.

[102] Biber K, Pinto-Duarte A, Wittendorp MC, Dolga AM, Fernandes CC, Von Frijtag Drabbe Künzel J, Keijser JN, de Vries R, Ijzerman AP, Ribeiro JA, Eisel U, Sebastião AM, Boddeke HW (2008) Interleukin-6 upregulates neuronal adenosine A1 receptors: implications for neuromodulation and neuroprotection. Neuropsychopharmacology 33, 2237-2250.

[103] Simonato M, Tongiorgi E, Kokaia M (2006) Angels and demons: neurotrophic factors and epilepsy. Trends Pharmacol Sci 27, 631-638. 
[104] Sebastião AM, Macedo MP \& Ribeiro JA (2000) Tonic activation of $\mathrm{A}_{2 A}$ adenosine receptors unmasks, and of $\mathrm{A}_{1}$ receptors prevents, a facilitatory action of calcitonin generelated peptide in the rat hippocampus. Br J Pharmacol 129, 374-380.

[105] El Yacoubi M, Ledent C, Parmentier M, Bertorelli R, Ongini E, Costentin J, Vaugeois JM (2001) Adenosine A2A receptor antagonists are potential antidepressants: evidence based on pharmacology and $\mathrm{A} 2 \mathrm{~A}$ receptor knockout mice. $\mathrm{Br} J$ Pharmacol 134, 68-77.

[106] El Yacoubi M, Costentin J, Vaugeois JM (2003) Adenosine A2A receptors and depression. Neurology 61, S72-73.

[107] Mingote S, Font L, Farrar AM, Vontell R, Worden LT, Stopper CM, Port RG, Sink KS, Bunce JG, Chrobak JJ, Salamone JD (2008) Nucleus accumbens adenosine A2A receptors regulate exertion of effort by acting on the ventral striatopallidal pathway. J Neurosci 28, 9037-9046.

[108] Kaster MP, Rosa AO, Rosso MM, Goulart EC, Santos AR, Rodrigues AL (2004) Adenosine administration produces an antidepressant-like effect in mice: evidence for the involvement of A1 and A2A receptors. Neurosci Lett 355, 21-24.

[109] Kaster MP, Budni J, Santos AR, Rodrigues AL (2007) Pharmacological evidence for the involvement of the opioid system in the antidepressant-like effect of adenosine in the mouse forced swimming test. Eur J Pharmacol 576, 91-98.

[110] Cunha RA, Sebastião AM, Ribeiro JA (1998) Inhibition by ATP of hippocampal synaptic transmission requires localized extracellular catabolism by ecto-nucleotidases into adenosine and channeling to adenosine A1 receptors. J Neurosci 18 , 1987-1995.

[111] Castrén E, Võikar V, Rantamäki T (2007) Role of neurotrophic factors in depression. Curr Opin Pharmacol 7, 18-21.

[112] Kozisek ME, Middlemas D, Bylund DB. (2008) Brainderived neurotrophic factor and its receptor tropomyosinrelated kinase $B$ in the mechanism of action of antidepressant therapies. Pharmacol Ther 117, 30-51.

[113] Lara DR, Dall'Igna OP, Ghisolfi ES, Brunstein MG (2006)
Involvement of adenosine in the neurobiology of schizophrenia and its therapeutic implications. Prog Neuropsychopharmacol Biol Psychiatry 30, 617-629.

[114] Fuxe K, Ferré S, Genedani S, Franco R, Agnati LF (2007) Adenosine receptor-dopamine receptor interactions in the basal ganglia and their relevance for brain function. Physiol Behav 92, 210-217.

[115] Akhondzadeh S, Shasavand E, Jamilian H, Shabestari O, Kamalipour A (2000) Dipyridamole in the treatment of schizophrenia: adenosine-dopamine receptor interactions. $J$ Clin Pharm Ther 25, 131-137.

[116] Ross CA, Margolis RL, Reading SA, Pletnikov M, Coyle JT (2006) Neurobiology of schizophrenia. Neuron 52, 139-153.

[117] Hoehn K, White TD (1989) Evoked release of endogenous adenosine from rat cortical slices by $\mathrm{K}+$ and glutamate. Brain Res 478, 149-151.

[118] Schotanus SM, Fredholm BB, Chergui K (2006) NMDA depresses glutamatergic synaptic transmission in the striatum through the activation of adenosine A1 receptors: evidence from knockout mice. Neuropharmacology 51, 272-282.

[119] Nikbakht MR, Stone TW (2001) Suppression of presynaptic responses to adenosine by activation of NMDA receptors. Eur J Pharmacol 427, 13-25.

[120] Sebastião AM, de Mendonça A, Moreira T \& Ribeiro, JA (2001) Activation of synaptic NMDA receptors by action potential-dependent release of transmitter during hypoxia impairs recovery of synaptic transmission upon reoxygenation. J Neurosci 21, 8564-8571.

[121] Wirkner K, Gerevich Z, Krause T, Günther A, Köles L, Schneider D, Nörenberg W, Illes P (2004) Adenosine A2A receptor-induced inhibition of NMDA and GABAA receptormediated synaptic currents in a subpopulation of rat striatal neurons. Neuropharmacology 46, 994-1007.

[122] Uhlhaas PJ, Singer W (2006) Neural synchrony in brain disorders: relevance for cognitive dysfunctions and pathophysiology. Neuron 52, 155-168. 